\title{
Are we preventing flood damage eco-efficiently? An integrated method applied to post-disaster emergency actions
}

\author{
Anna Petit-Boix ${ }^{\mathrm{a}, *}$, Ana Arahuetes ${ }^{\mathrm{b}}$, Alejandro Josa ${ }^{\mathrm{c}, \mathrm{d}}$, Joan Rieradevall ${ }^{\mathrm{a}, \mathrm{e}}$, Xavier Gabarrell $^{\mathrm{a}, \mathrm{e}}$
}

aSostenipra (ICTA-IRTA-Inèdit; 2014 SGR 1412) Institute of Environmental Science and Technology (ICTA; Unidad de excelencia «María de Maeztu» (MDM-2015-0552)), Universitat Autònoma de Barcelona (UAB), Edifici ICTA-ICP, Carrer de les Columnes, 08193 Bellaterra, Barcelona, Spain.

bInteruniversity Institute of Geography, Universidad de Alicante, Edificio de Institutos Universitarios, Apartado de Correos, 99, 03080 Alicante, Spain.

${ }^{\mathrm{c}}$ Department of Civil and Environmental Engineering, School of Civil Engineering, UPC-Camins BarcelonaTECH, Universitat Politècnica de Catalunya (UPC), Jordi Girona 1-3, Building D2, Barcelona, Spain.

dInstitute of Sustainability (IS.UPC), Universitat Politècnica de Catalunya (UPC-BarcelonaTech), Jordi Girona 31, Barcelona, Spain.

eDepartment of Chemical, Biological and Environmental Engineering, Xarxa de Referència en Biotecnologia (XRB), School of Engineering (ETSE), Universitat Autònoma de Barcelona (UAB), Campus of the UAB, Bellaterra (Cerdanyola del Vallès), 08193 Barcelona, Catalonia, Spain.

*Corresponding author: Anna Petit Boix (anna.petit@uab.cat). Sostenipra (ICTA-IRTA-Inèdit; 2014 SGR 1412), Institute of Environmental Science and Technology (ICTA; Unidad de excelencia «María de Maeztu» (MDM-20150552)), Universitat Autònoma de Barcelona (UAB), Edifici ICTA-ICP, Carrer de les Columnes, 08193 Bellaterra, Barcelona, Spain.

Post-print of Petit-Boix, Anna et al. «Are we preventing flood damage ecoefficiently? An integrated method applied to post-disaster emergency actions» in Science of the total environment (Elsevier). Vol. 580 (February 2017), p. 873-881. The final version is available at DOI 10.1016/j.scitotenv.2016.12.034 


\section{ABSTRACT}

Flood damage results in economic and environmental losses in the society, but flood prevention also entails an initial investment in infrastructure. This study presents an integrated ecoefficiency approach for assessing flood prevention and avoided damage. We focused on ephemeral streams in the Maresme region (Catalonia, Spain), which is an urbanized area affected by damaging torrential events. Our goal was to determine the feasibility of post-disaster emergency actions implemented after a major event through an integrated hydrologic, environmental and economic approach. Life cycle assessment (LCA) and costing (LCC) were used to determine the eco-efficiency of these actions, and their net impact and payback were calculated by integrating avoided flood damage. Results showed that the actions effectively reduced damage generation when compared to the water flows and rainfall intensities registered. The eco-efficiency of the emergency actions resulted in $1.2 \mathrm{~kg} \mathrm{CO}$ eq. per invested euro. When integrating the avoided damage into the initial investment, negative net impacts were obtained (e.g., $-5.2 \mathrm{E}+05 €$ and $-2.9 \mathrm{E}+04 \mathrm{~kg} \mathrm{CO} 2$ eq. per event), which suggests that these interventions contributed with environmental and economic benefits to the society. The economic investment was recovered in two years, whereas the design could be improved to reduce their environmental footprint, which is recovered in 25 years. Our method and results highlight the effects of integrating the environmental and economic consequences of decisions at an urban scale and might help the administration and insurance companies in the design of prevention plans and climate change adaptation.

KEYWORDS: risk management, life cycle assessment, life cycle costing, damage prevention, climate change

\section{INTRODUCTION}


Climate change and the increase in urban population pose a problem to flood risk management. By 2050 cities are expected to host 70\% of the world's population (UN, 2012), resulting in more urban infrastructure and altering soil infiltration and natural watercourses. Floods are responsible for $34 \%$ of the global natural disasters (Guha-Sapir et al., 2009), and their management is especially complex in urban areas. The Spanish Mediterranean coast is an example. In this region, ephemeral streams are common hydrologic features that are typically dry except during torrential rainfall events that result in flooding. Some of the factors that increase the occurrence of these events are land use change, vegetation and soil removal and the construction of drainage networks. Therefore, prevention and mitigation strategies are essential for managing floods and reducing urban and natural damage (Barbosa et al., 2012). In the case of Spanish ephemeral streams, some engineering solutions include channeling or undergrounding the stream or regular maintenance activities. Still, flood damage amounts to 3E+09 USD/year worldwide (around 2.6E+09 euros $-€)($ Guha-Sapir et al., 2009). In Spain, the average insurance compensations for flood damage (e.g., lost properties, vehicles, etc.) reached 150 million euros/year from 1990 to 2014 (Insurance Compensation Consortium, 2015).

In the framework of sustainability, the consequences of flooding result in environmental and economic impacts at two different scales. On the one hand, damaged goods such as buildings or personal properties must be replaced or re-constructed, which requires materials, energy and money. On the other hand, prevention and mitigation strategies are often associated with investing physical and monetary resources for designing and constructing infrastructure. At this point, it is interesting to determine the environmental and economic balance of prevention and mitigation strategies with respect to the damage that they might prevent. 
Existing articles proposed methods for integrating flood risk, prevention and damage. Most of the analyses simulated the hydrologic performance of different scenarios based on climate change predictions, control policies or alternative management systems and provided socioeconomic results (Brouwer and van Ek, 2004; Haynes et al., 2008; Jonkman et al., 2008; Kubal et al., 2009; Zhou et al., 2012). These might include physical (e.g., building damage) and/or intangible costs (e.g., traffic delays or impacts on health). Cost-benefit analysis was usually the method applied to determine the economic feasibility of management alternatives (Jonkman et al., 2008; Zhou et al., 2012). The integration of environmental or ecological damage is more complex, but some studies attempted to include this dimension by estimating the potential damage to groundwater or biodiversity, for example (Brouwer and van Ek, 2004; Kubal et al., 2009). However, we still need to clearly define the environmental and economic impacts of flood prevention strategies in terms of investment and damage generation. In this context, post-disaster emergency actions are a field to explore, as the urgent need for urban restoration might lead to the application of economically and environmentally inefficient strategies.

To determine the environmental and economic investment in infrastructure, life cycle assessment (LCA) and life cycle costing (LCC) are commonly applied. Several studies on best management practices dealt with innovative systems, such as green roofs and retention systems (see for instance Flynn and Traver, 2013; Kosareo and Ries, 2007; Petit-Boix et al., 2015), but rehabilitation or post-disaster restoration strategies were not assessed, and neither were flood damage costs. However, this analysis is essential to provide an estimation of the eco-efficiency of the strategies, which is a measure of the environmental performance of a system in relation to its value (ISO 14045:2012) that helps to determine its feasibility through a bi-dimensional approach. When dealing with post-disaster emergency actions, this assessment should help 
reduce the economic investment while generating fewer environmental impacts. To our knowledge, the eco-efficiency approach was not applied to flood studies in the past.

This paper seeks to integrate post-disaster emergency actions and flood damage generation in hydrologic, environmental and economic terms with the aim of eco-efficiently planning prevention strategies in the future. We try to answer the following question: Are post-disaster emergency actions feasible when compared to the economic and environmental damage generated by floods? Our goal was to provide a method for estimating the environmental and economic balance and payback period of flood prevention from an eco-efficiency standpoint. This approach might facilitate and foster eco-innovation in the field of disaster management. We tested this method in the coast of Catalonia (Spain), where the combination of torrential rainfall and urbanized ephemeral streams poses a significant risk. This analysis was based on historical data and specific torrential events, as previous hydrologic analyses identified the need to focus on particular damaging events and their associated consequences instead of providing general inaccurate statistics (Olcina and Rico, 2000).

\section{METHODS}

Figure 1 illustrates the method applied for estimating the environmental and economic balance and payback period of implementing post-disaster emergency actions. The application of the method is detailed in the following sections.

$<$ Figure 1 $>$

\subsection{Case study}

The ephemeral streams under analysis are located in the Maresme region (Barcelona) (Table 1). The streams are called Vilassar, Cabrils and Cintet - hereinafter, streams A, B and C, 
respectively. Stream A rises from the city of Vilassar de Dalt, and streams B and C, from the city of Cabrils. All of them flow into the city of Vilassar de Mar and, finally, into the Mediterranean Sea. These streams are composed of granitic bedrock with a depth of fifteen meters, covered by an intermediate substrate of altered granites and sublevels of quaternary alluvial sands coming from the stream itself. The areas affected by streams A, B and C are 557, 569 and 445 hectares, respectively (Junta d'Aigües, 1992).

Since the early 90s, these cities have experienced an intense urban growth (see Supporting Information 1) and the population has doubled. In 2015, Vilassar de Dalt, Vilassar de Mar and Cabrils had a population of 8,964, 20,447 and 7,250, respectively (Idescat, 2016). Some consequences that resulted from this process include land use changes, construction of lowdensity neighborhoods, and a shift from agriculture to intensive greenhouse production and industries. As a result, between 1986 and 1996 the surface water flow increased by $4.5 \%$ and $54 \%$ in streams B and C, respectively (Lleonart and Tarruella, 2010).

In the last 20 years, flood prevention plans became more relevant, especially since the great torrential event that took place in September 1996, which resulted in almost 3 million euros of damage compensations and casualties (Insurance Compensation Consortium, 2015). In November/December 1996 a set of post-disaster emergency actions were implemented to improve the channels and complement previous interventions. These actions affected the three cities and mainly consisted of adapting the existing channels by (re)constructing concrete walls and ripraps in strategic areas (Table 1). In addition to these interventions, there were improvements at a smaller scale and certain areas of the streams were buried when located in urbanized areas. 
$<$ Table 1 $>$

\subsection{Hydrologic characterization}

Historical data were used to assess water flows and rainfall intensity. A total of 50 damaging events were considered for the period from 1996 to 2014. This information should be handled with care, as the flash floods that result from torrential events in this area do not perfectly fit in the methodologies developed for estimating water flows (Barrera et al., 2006). In the Mediterranean coast, floods are produced by torrential events, not by series of precipitations. These are sudden events that do not require previous or subsequent days of rainfall and which occur punctually and with localized torrentiality.

The methodology applied by the Catalan Water Agency (2003) was used to identify the hydrologic features of the streams and determine their behavior during flooding events. First, the maximum daily rainfall was calculated following the guidelines published by the Spanish Ministry of Development (1999) and applying Equation (1) with a regional correction factor of 1.2 for the area under study (Junta d'Aigües, 1992).

$X_{t}=Y_{t} \times P \quad$ Equation (1)

where $\mathrm{X}_{\mathrm{t}}$ : maximum rainfall (in $\mathrm{mm}$ ) for the return period considered; $\mathrm{Y}_{\mathrm{t}}$ : regional quantile resulting from a tabulated value obtained by $\mathrm{Cv}$ (coefficient of variation; dimensionless) and $\mathrm{T}$ (return period; in years); P: maximum annual daily rainfall (in $\mathrm{mm}$ ).

Second, using the data obtained through Equation (1), we calculated the peak flows $\left(\mathrm{Q}_{\mathrm{p}}\right)$ for different return periods (i.e., 50, 100 and 500 years), according to an update of the Rational Method by Témez (1991) (Equation (2) - for detailed equations, see Supporting Information 2). With $Q_{p}$ we can identify whether the water flow estimated for each event $(Q)$ was above or below the expected flows of the watershed. 
$\mathrm{Q}_{\mathrm{p}}=\mathrm{k} \times \frac{\mathrm{RC} \times \mathrm{I} \times \mathrm{A}}{3.6} \quad$ Equation (2)

where $\mathrm{Q}_{\mathrm{p}}$ : the maximum flow $\left(\mathrm{m}^{3} / \mathrm{s}\right)$; $\mathrm{k}$ : uniformity coefficient (adimensional), based on Témez (1991); RC: threshold runoff coefficient (due to data availability, we calculated C for streams A and $\mathrm{C}$ and applying an interval between 0.4 and 0.6 according to literature values (Aparicio, 1999); I: rainfall intensity $(\mathrm{mm} / \mathrm{h})$, and A: watershed area $\left(\mathrm{km}^{2}\right)$.

In addition, the features of the channels constructed in some sections of the streams were reviewed (Junta d'Aigües, 1992). Note that these values might be underestimated given the lack of hourly rainfall intensity data and rain gauges (Catalan Water Agency, 2016; RuralCat, 2016), which is a shortcoming of this type of analysis (Camarasa Belmonte and Segura Beltrán, 2001). Given data availability, most of the collected hydrologic parameters correspond to stream B, whereas peak flows for streams $\mathrm{A}$ and $\mathrm{C}$ were extrapolated based on stream $\mathrm{B}$. As a result, flow ranges were obtained depending on the threshold runoff, considering the maximum flow rate range as worst case scenario (see Supporting Information 2).

\subsection{Post-disaster emergency actions: environmental and economic assessment}

The environmental and economic performance of the emergency actions was estimated from a life cycle perspective. The environmental impacts were calculated using the LCA methodology (ISO 14040:2006), whereas the economic costs were provided through LCC (ISO 156865:2008). Based on the ISO standards, we describe the assessment phases in the following sections, i.e., goal and scope definition, inventory assessment, impact assessment and interpretation. The eco-efficiency of the system was obtained by combining the environmental and economic results (ISO 14045:2012). 


\subsubsection{Goal and Scope of the LCA and LCC}

The functional unit (FU) of this analysis was the implementation of a set of post-disaster emergency actions (A1 to A7) for re-constructing and conditioning ephemeral streams A, B and $\mathrm{C}$ after a destructive flooding event. The lifespan of these actions was set at 50 years, which was the minimum return period considered.

For each of the emergency actions implemented in the area, the system boundaries considered were the preparation of the affected site, raw material extraction and transport to the construction site, (re)construction of the infrastructure, and transport and disposal of the demolition waste resulting from the preparation phase (Figure 2). The operation and maintenance were considered negligible because the infrastructure typically requires little maintenance.

$<$ Figure 2>

\subsubsection{Life cycle inventory (LCI)}

An inventory of the materials, energy and processes involved in each life cycle stage was composed considering physical quantities and economic costs (a breakdown of the quantities and costs is provided in Supporting Information 3). In the case of the LCC, the labor costs were also included. Data were retrieved from the original projects, expenditure records and project files provided by the archive of the Catalan Water Agency (2015). Additional data for some missing construction items were obtained from MetaBase ITeC (2010) and CYPE Ingenieros (2015) and validated with the expenditure records. An average distance of $30 \mathrm{~km}$ was considered for the transport of local materials, such as concrete, cement or wood (Petit-Boix et al., 2016; Sanjuan-Delmás et al., 2014). Plastics and metals covered $100 \mathrm{~km}$ until the construction site. The distance to the landfill was $10 \mathrm{~km}$ (Petit-Boix et al., 2016). Note that the economic cost of 
material transport was embedded in the cost of material procurement and is not shown in the results. The ecoinvent v3 database (Weidema et al., 2013) was used for retrieving background data on the environmental life cycle of materials and processes.

\subsubsection{Life cycle impact assessment (LCIA) and economic analysis}

For calculating the environmental impacts related to the LCI, the classification and characterization processes included in the LCIA step were considered. The $\operatorname{ReCiPe}(\mathrm{H})$ method was applied (Goedkoop et al., 2009) through the Simapro 8.0.4 software (PRé Consultants, 2014). The midpoint indicators included were Climate Change Potential (CCP, $\mathrm{kg} \mathrm{CO}_{2}$ eq.), Ozone Depletion Potential (ODP, kg CFC-11 eq.), Human Toxicity Potential (HTP, kg 1,4-DB eq.), Photochemical Oxidant Formation Potential (PCOP, kg NMVOC), Terrestrial Acidification Potential (TAP, kg $\mathrm{SO}_{2}$ eq.), Freshwater Eutrophication Potential (FEP, kg P eq.), Marine Eutrophication Potential (MEP, kg $\mathrm{N}$ eq.), Water Depletion Potential (WDP, $\mathrm{m}^{3}$ ), Metal Depletion Potential (MDP, kg Fe eq.) and Fossil Depletion Potential (FDP, kg oil eq.). The Cumulative Energy Demand V1.08 (CED, MJ)(Hischier et al., 2010) was also selected to evaluate energy issues.

In the economic analysis, we estimated the Total Cost (TC, euros - $€$ ) associated with the emergency actions. Because the original projects were based on the year 1996, we calculated the TC for 2015 by applying the Spanish inflation rates for the period from 1996 to 2015 (IMF, 2015). According to BOE (2001b), $19 \%$ of indirect costs and $16 \%$ of value-added tax were added to the life cycle costs to obtain the TC value.

\subsection{Flood damage: environmental and economic assessment}


A series of flood damage data were supplied by the Spanish Insurance Compensation Consortium. These covered the events that occurred after implementing the emergency actions described in Section 2.3. Data accounted for physical damage, but resulting intangible damage, such as traffic delays or health issues, was not included due to its complexity. Physical damage was divided into damage to vehicles, residential buildings, industries and businesses and warehouses, and referred to the three cities affected by Streams A, B and C. This information was the result of expert appraisals conducted by insurance companies and was supposed to compensate insurance holders for flood damage. Because uninsured population was not included in the assessment, the economic loss was probably underestimated.

As opposed to the emergency actions (Section 2.3), damage compensations were recorded in economic terms and no physical or environmental data were available. In this approach, we used national input-output tables (INE, 2015) and related greenhouse gas emission tables (INE, 2014) to convert the economic compensations into environmental impacts. To do so, we selected the economic sectors involved in the life cycle of each damage category (Table 2) and averaged their impact factor (i.e., $\mathrm{kg} \mathrm{CO}_{2}$ eq./€). This value was applied to the economic compensation data, as illustrated in Supporting Information 4.

$<$ Table 2>

\subsection{Eco-efficiency metric and environmental and economic balance}

The indicators that resulted from this assessment were a set of eco-efficiency ratios related to the investment in infrastructure, and the net impact and payback period that combined the investment and flood damage prevention. 
The eco-efficiency of the post-disaster emergency actions was assessed by selecting one of the eco-efficiency indicators proposed by ISO 14045:2012. We chose an eco-efficiency ratio that depicts the environmental performance divided by the product system value, which might represent the environmental intensity of production (Huppes and Ishikawa, 2005). This metric was only applied to the investment assessment.

The net impact and payback period were estimated in environmental and economic terms. We assumed that the implementation of the emergency actions avoided material damage. The damage resulting from a hypothetical do-nothing scenario was estimated by applying the ratio damage-water flow of 1996 to the water flow of each registered event (see Supporting Information 5). The avoided damage was obtained by subtracting the recorded damage from the do-nothing scenario. Equations (3) and (4) were applied to estimate the net impact and payback period.

$\mathrm{NIE}=\frac{\mathrm{TII}}{\mathrm{L} \times \mathrm{E}}-(\mathrm{DND}-\mathrm{RD}) \quad$ Equation (3)

$\mathrm{PP}=\frac{\mathrm{TII}}{\mathrm{DND}-\mathrm{RD}} \quad$ Equation (4)

where NIE: net impact per event; TII: total initial investment; L: lifespan of the system (years); E: average number of events per year; DND: average do-nothing damage per event; RD: average recorded damage per event; PP: payback time (in number of events).

\section{RESULTS AND DISCUSSION}

In this section we present the hydrologic evaluation of the watershed (Section 3.1), the impacts associated with the investment in infrastructure (Section 3.2) and damage compensation (Section 3.3) and the economic and environmental feasibility of the actions (Section 3.4). 


\subsection{Hydrologic performance of the watershed}

Using Equation (2), we calculated the water flow in Stream B, which is the main stream in the area. A flow of $78.2 \mathrm{~m}^{3} / \mathrm{s}$ would be expected for a return period of 50 years (Table 3). This is the return period considered in Spanish regulations (BOE, 2001b) and flood studies conducted in the same area (San Millán, 2008). None of the observed events with the greatest flows exceeded this value (Table 3), and yet damage was registered in the three cities. However, this is not surprising, as the localized torrential events that affect the Mediterranean coast not always relate to the return periods (Olcina and Rico, 2000). Thus far, flooding has not generated as much damage as the 1996 event, mainly because the post-disaster interventions might have mitigated its effects.

$<$ Table 3>

Another aspect to consider is the rainfall intensity. The magnitude of the rainfall intensity becomes more important than the amount of water accumulated during the event, as higher intensities generated greater economic losses. Heavy precipitation in a short period of time results in the inability of the soil to absorb water, thereby increasing runoff that might cause more damage (Barrera et al., 2006; Olcina, 1994). This fact is aggravated by the increase in artificial urbanized surface. In light of the results, the emergency actions seemed to be effective when reducing the effects of flooding, albeit the land use changes that took place in the past.

\subsection{The investment: impacts and costs of the emergency actions}

The LCA and LCC provided with overall impact and eco-efficiency results (Table 4) related to the implementation of the emergency actions. In general terms, these actions resulted in 3.9E+06 $\mathrm{kg}$ of $\mathrm{CO}_{2}$ eq. emissions and an economic investment of $3.2 \mathrm{E}+06 €$. These values lead to an ecoefficiency ratio of $1.2 \mathrm{~kg}$ of $\mathrm{CO}_{2}$ per invested euro. 
$<$ Table 4>

The major contributors to the environmental impacts were concrete and related steel reinforcements (Figure 3), which were the main materials applied in the (re)construction of walls and other structural elements. Their joint impacts accounted for 30-90\% of the impacts, depending on the impact indicator. Another relevant process was the use of construction machinery, which had a maximum contribution of $50 \%$ in the Photochemical Oxidant Formation Potential due to the emissions that result from burning diesel. Machinery was also relevant in economic terms (33\% of the costs) because of the time dedicated to each engineering process. These results might vary depending on the type of machinery used in the projects. Labor represented $20 \%$ of the total costs and was the third main contributor to TC after the machinery and reinforced concrete.

$<$ Figure 3>

\subsection{The loss: impacts and costs of flood damage}

According to the data provided by the Insurance Compensation Consortium, the losses from 1996 that led to the implementation of the emergency actions amounted to $2.6 \mathrm{E}+06 €$ and $2.7 \mathrm{E}+05 \mathrm{~kg}$ of $\mathrm{CO}_{2} \mathrm{eq}$, when a maximum rainfall intensity of $176 \mathrm{~mm} / \mathrm{h}$ was registered (see Supporting Information 5). The historical damage recorded afterwards is shown in Figure 4. In general, events that resulted in more than $20,000 €$ of losses mainly consist of damage to residential buildings, which accounted for a minimum of $40 \%$ of the economic compensations. Vehicle damage was also relevant in these events (15-35\% of the costs). Because ephemeral streams are usually dry, vehicles are occasionally parked in the streambeds and water drags them during torrential events. 
This pattern was similar when analyzing the environmental results, but the contribution of vehicles was barely noticeable. This outcome is related to the $\mathrm{CO}_{2}$ conversion factors that we estimated for the car production. The impact factor applied in this case was between eight and ten times lower than that applied to the other damage categories (Table 2). In the latter, damage to electricity and gas networks was considered, which resulted in the highest impact $(0.86 \mathrm{~kg}$ $\mathrm{CO}_{2}$ eq./€) compared to other affected sectors.

Figure 4 also illustrates the evolution of flood damage after implementing the emergency actions. As mentioned in Section 3.1, the water flow did not surpass the design flow in any of the cases. The hydrologic data presented in Figure $\mathbf{4}$ are related to accumulated water flows, but intensity plays a key role in damage generation. For instance, in 1998 and 1999 two events resulted in similar water flows, but the maximum intensity was greater in $1999(132 \mathrm{~mm} / \mathrm{h})$ than in $1998(55.2 \mathrm{~mm} / \mathrm{h})$. Nonetheless, during this 17 -year period, it seems that damage generation was lower when compared to 1996. The event that led to these measures registered an estimated water flow of $42.7 \mathrm{~m}^{3} / \mathrm{s}$. To date, some events resulted in water flows that ranged from 20 to 30 $\mathrm{m}^{3} / \mathrm{s}$ (see Supporting Information 5), but the damage generated was lower than the previous registers. This outcome could be related to the rainfall intensity, which was lower, and the implementation of the emergency actions (Section 3.1). However, some of the events that generated damage could not be associated with rainfall data due to data availability and the location of the rain gauges.

$<$ Figure 4>

\subsection{The balance: investment versus loss}


The data generated in Sections 3.2 and 3.3 was used to estimate the net environmental balance of the emergency actions implemented in the area (Table 5). When accounting for the net impacts, the negative values $\left(-5.2 \mathrm{E}+05 €\right.$ and $-2.9 \mathrm{E}+04 \mathrm{~kg} \mathrm{CO}_{2}$ eq.) suggest that these emergency actions contribute with environmental and economic benefits. The average damage recorded after the interventions represented $2.5 \%$ of the loss estimated for the do-nothing scenario. With regard to the payback period, the initial economic investment was recovered two years after the intervention. In this sense, this set of emergency actions was economically feasible with respect to the damage they prevented.

In environmental terms, results differed, as 25 years were needed to offset the initial $\mathrm{CO}_{2}$ emissions resulting from the project. However, different factors might affect these values and their associated uncertainty. We did not include potential ecosystem services that might result from the emergency actions, such as social or natural benefits. These might reduce the environmental investment because of their positive effect on the system. Future analyses should improve this aspect to better depict the absolute environmental impacts of emergency actions. Other aspects that might increase the environmental payback and related uncertainty are lifespan and material intensity of the infrastructure and damaged products. For instance, vehicles and electric appliances generally have a shorter lifespan than built infrastructure. In the latter, the use of materials tends to be intensive to increase their durability and, thus, the initial investment might be higher than that of a car. This might lead to re-thinking the type and quantity of materials and designs applied in the reconstruction of this type of infrastructure or to implementing green systems with a shorter environmental payback. Finally, the environmental impacts of losses might be underestimated because average characterization factors were applied using input-output tables. In this case, data on specific damaged items within the damage 
categories is needed, such as basement furniture, household appliances, etc. Future assessments should consider this limitation and provide particular environmental values for these items.

$<$ Table 5>

\section{CONCLUSIONS}

The results obtained in this paper highlight the effects of integrating the consequences of decisions into the life cycle of urban interventions, such as flood prevention strategies. Accounting for costs and benefits is especially common in companies, where revenue can easily be calculated and balanced with the investment. However, it is also interesting to couple these parameters at an urban scale, as they might be responsible for a share of the total impacts of cities. Thus, this type of assessment might offer data to the local administration and insurance companies for improving the sustainability of cities. In this particular case, communicating the economic and environment payback of the emergency actions, i.e., 2 and 25 years, respectively, might have an impact on their future decisions once they are aware of the actual feasibility of their systems. Additionally, eco-efficiency indicators will give them information about the impacts related to each invested euro (e.g., $1.2 \mathrm{~kg}$ of $\mathrm{CO}_{2} / €$ ). In the field of environmental management, this approach is yet to be explored in detail, but it is key to ensure the sustainability of any action and decision made at an urban scale. This study is thus a first step towards integrating the environmental and economic dimensions for assessing flood prevention and we believe this can be applied and adapted to different types of infrastructure.

Furthermore, adapting to climate change is essential for dealing with future extreme events. When emergencies occur, damage restoration and risk prevention are a priority and any action is acceptable to recover from a disaster. However, if emergency situations need to be dealt with 
very often, the eco-efficiency of the solutions should be considered to reduce the resource consumption, impact generation and economic investment.

\section{ACKNOWLEDGMENT}

We wish to thank the Catalan Water Agency and the Insurance Compensation Consortium for supporting and providing data, specially Alfonso Nájera. We thank Dr Jorge Olcina and Dr David Saurí for their valuable advice in the field of flood management. We would also like to thank the Spanish Ministry of Education for the grant awarded to A. Petit-Boix (FPU13/01273) to conduct this research, and the Catalan Government for the SGR funds (2014 SGR 1412); as well as de grant awarded to A. Arahuetes (FPI2013-066273/project CSO2012-36997-CO2-02) by the Spanish Ministry of Economy and Finance and her mobility grant (EEBB-I-15-10197).

\section{REFERENCES}

Aparicio, F., 1999. Fundamentos de hidrología de superfície. Limusa, México.

Barbosa, A.E., Fernandes, J.N., David, L.M., 2012. Key issues for sustainable urban stormwater management. Water Res. 46, 6787-6798. doi:10.1016/j.watres.2012.05.029

Barrera, A., Llasat, M.C., Barriendos, M., 2006. Estimation of extreme flash flood evolution in Barcelona County from 1351 to 2005. Nat. Hazards Earth Syst. Sci. 6, 505-518. doi:10.5194/nhess-6-505-2006

BOE, 2001a. Real Decreto 1098/2001 de 12 de octubre, por el que se aprueba el Reglamento general de la Ley de Contratos de las Administraciones Públicas 257.

BOE, 2001b. Real Decreto Legislativo 1/2001, de 20 de julio, por el que se aprueba el texto refundido de la Ley de Aguas (BOE-A-2001-14276) 176. 
Brouwer, R., van Ek, R., 2004. Integrated ecological, economic and social impact assessment of alternative flood control policies in the Netherlands. Ecol. Econ. 50, 1-21. doi:10.1016/j.ecolecon.2004.01.020

Camarasa Belmonte, A.M., Segura Beltrán, F., 2001. Flood events in Mediterranean ephemeral streams (ramblas) in Valencia region, Spain. CATENA 45, 229-249. doi:10.1016/S03418162(01)00146-1

Catalan Water Agency, 2016. Data consultation.

Catalan Water Agency, 2015. Official project documents provided by the archive of the Catalan Water Agency, Barcelona.

Catalan Water Agency, 2003. Technical recommendations for flooding studies at a local level (Recomanacions tècniques per als estudis dínundabilitat d'àmbit local). Barcelona, Spain.

CYPE Ingenieros, 2015. Construction costs generator [Generador de precios de la construcción] http://Www.generadordeprecios.info/ [WWW Document].

Flynn, K.M., Traver, R.G., 2013. Green infrastructure life cycle assessment: A bio-infiltration case study. Ecol. Eng. 55, 9-22. doi:10.1016/j.ecoleng.2013.01.004

Goedkoop, M., Heijungs, R., Huijbregts M, De Schryver A, Struijs J, Van Zelm, R., 2009. ReCiPe 2008, A Life Cycle Impact Assessment Method Which Comprises Harmonised Category Indicators at the Midpoint and the Endpoint Level. Report I: Characterisation, First Ed. ed. Available at: http://www.lcia-recipe.net.

Guha-Sapir, D., Below, R., Hoyois, P., 2009. EM-DAT: International Disaster Database. Université Catholique de Louvain - Brussels - Belgium [WWW Document]. URL 
www.emdat.be Accessed December 2014

Haynes, H., Haynes, R., Pender, G., 2008. Integrating socio-economic analysis into decisionsupport methodology for flood risk management at the development scale (Scotland). Water Environ. J. 22, 117-124. doi:10.1111/j.1747-6593.2007.00086.x

Hischier, R., Weidema, B., Althaus, H., Bauer, C., Doka, G., Dones, R., Frischknecht, R., Hellweg, S., Humbert, S., Jungbluth, N., Köllner, T., Loerincik, Y., Margni, M., Nemecek, T., 2010. Implementation of Life Cycle Impact Assessment Methods. Final report ecoinvent v2.2 No. 3.

Huppes, G., Ishikawa, M., 2005. Eco-efficiency and Its Terminology. J. Ind. Ecol. 9, 43-46. doi:10.1162/108819805775247891

Idescat. Statistical Institute of Catalonia, 2016. Municipal database [WWW Document]. URL http://www.idescat.cat/territ/BasicTerr?TC=9

IMF. International Monetary Fund, 2015. World Economic Outlook Database [WWW Document]. URL http://www.imf.org/external/pubs/ft/weo/2014/01/weodata/weorept.aspx?sy=2008\&ey=201 $4 \& \operatorname{scsm}=1 \& \operatorname{ssd}=1 \&$ sort $=$ country\&ds $=. \& b r=1 \& p r 1 . x=47 \& p r 1 . y=4 \& c=223 \& s=P C P I E \% 252$ CPCPIEPCH\&grp $=0 \& a=$ Accessed October 2014

INE. Spanish Statistical Office, 2015. Spanish National Accounting, 2010. http://www.ine.es/jaxi/menu.do?type=pcaxis \&path=/t35/p008/\&file=inebase [WWW Document].

INE. Spanish Statistical Office, 2014. Air emissions accounting, 2008-2012. 
http://www.ine.es/jaxi/Tabla.htm?path=/t26/p084/serie/10/\&file=01001.px\&L=0 [WWW Document].

Insurance Compensation Consortium (Consorcio de Compensación de Seguros), 2015. Extraordinary risks, Series 1971-2014 (Riesgos extraordinarios, Serie 1971-2014). Madrid, Spain.

ISO 14040:2006, n.d. Environmental management - Life cycle assessment - Principles and framework.

ISO 14045:2012, n.d. Environmental management — Ecoefficiency assessment of product systems — Principles, requirements and guidelines.

ISO 15686-5:2008, n.d. Buildings and constructed assets - Sevice-life planning - Part 5: Lifecycle costing.

Jonkman, S.N., Bočkarjova, M., Kok, M., Bernardini, P., 2008. Integrated hydrodynamic and economic modelling of flood damage in the Netherlands. Ecol. Econ. 66, 77-90. doi:10.1016/j.ecolecon.2007.12.022

Junta d'Aigües, 1992. Master plan for flood protection in Maresme (Pla Director de protecció contra avingudes al Maresme).

Kosareo, L., Ries, R., 2007. Comparative environmental life cycle assessment of green roofs. Build. Environ. 42, 2606-2613. doi:10.1016/j.buildenv.2006.06.019

Kubal, C., Haase, D., Meyer, V., Scheuer, S., 2009. Integrated urban flood risk assessment adapting a multicriteria approach to a city. Nat. Hazards Earth Syst. Sci. 9, 1881-1895. doi:10.5194/nhess-9-1881-2009 
Lleonart, I., Tarruella, X., 2010. Municipal urban plan of Cabrils - Preliminary sustainability report.

http://www.cabrils.cat/pdf/poum/av/textes/IAP\%20POUM\%20CABRILS_280210.pdf.

MetaBase ITeC, 2010. Online ITeC database: prices, technical details, companies, certificates, product pictures and environmental data [WWW Document]. URL http://www.itec.cat/metabase. Accessed February 2013

Olcina, J., 1994. Tormentas y granizadas en las tierras alicantinas. Instituto Universitario de Geografía, Alicante (Spain).

Olcina, J., Rico, A.M., 2000. Estudios sobre lluvias torrenciales e inundaciones en la Provincia de Alicante (1982-1999). Univ. Alcalá. Serv. Publicaciones 9, 71-92.

Petit-Boix, A., Roigé, N., de la Fuente, A., Pujadas, P., Gabarrell, X., Rieradevall, J., Josa, A., 2016. Integrated Structural Analysis and Life Cycle Assessment of Equivalent Trench-Pipe Systems for Sewerage. Water Resour. Manag. 30, 1117-1130. doi:10.1007/s11269-0151214-5

Petit-Boix, A., Sevigné-Itoiz, E., Rojas-Gutierrez, L.A., Barbassa, A.P., Josa, A., Rieradevall, J., Gabarrell, X., 2015. Environmental and economic assessment of a pilot stormwater infiltration system for flood prevention in Brazil. Ecol. Eng. 84, 194-201. doi:10.1016/j.ecoleng.2015.09.010

PRé Consultants, 2014. SimaPro 8.0.4. PRé Consultants, Amersfoort.

RuralCat, 2016. Agrometeorological data - Cabrils [WWW Document]. URL https://www.ruralcat.net/web/guest/agrometeo.estacions?p_p_id=234\&p_p_lifecycle=0\&p_ 
p_state=normal\&p_p_mode=view\&p_p_col_id=column-

3\&p_p_col_count=1\&_234_struts_action=\%2Fadasasistemas $\% 2$ Fagrometeo $\% 2$ Festacio

San Millán, J., 2008. Estudi d'inundabilitat de la Riera de Cabrils, al seu pas pel sector C/Manuel Roca - El Barato. Modificació puntual del Pla General d'Ordenació Urbanística Municipal. Vilassar de Mar (Maresme).

Sanjuan-Delmás, D., Petit-Boix, A., Gasol, C., Villalba, G., Suárez-Ojeda, M., Gabarrell, X., Josa, A., Rieradevall, J., 2014. Environmental assessment of different pipelines for drinking water transport and distribution network in small to medium cities: a case from Betanzos, Spain. J. Clean. Prod. 66, 588-598. doi:10.1016/j.jclepro.2013.10.055

Spanish Ministry of Development, 1999. Maximum daily rainfall in the Peninsular Spain (Máximas lluvias diarias en la España Peninsular). Madrid, Spain.

Témez, J., 1991. Extended and Improved Rational Method. Version of the Highways Administration of Spain. Proc. XXIV Congress. Madrid, Spain. Vol A.

UN. United Nations. Department of Economic and Social Affairs. Population Division, 2012. World Urbanization Prospects: The 2011 Revision, CD-ROM Edition.

Weidema, B., Bauer, C., Hischier, R., Mutel, C., Nemecek, T., Reinhard, J., Vadenbo, C., Wernet, G., 2013. The ecoinvent database: Overview and methodology, Data quality guideline for the ecoinvent database version 3, www.ecoinvent.org.

Zhou, Q., Mikkelsen, P.S., Halsnæs, K., Arnbjerg-Nielsen, K., 2012. Framework for economic pluvial flood risk assessment considering climate change effects and adaptation benefits. J. Hydrol. 414, 539-549. doi:10.1016/j.jhydrol.2011.11.031 


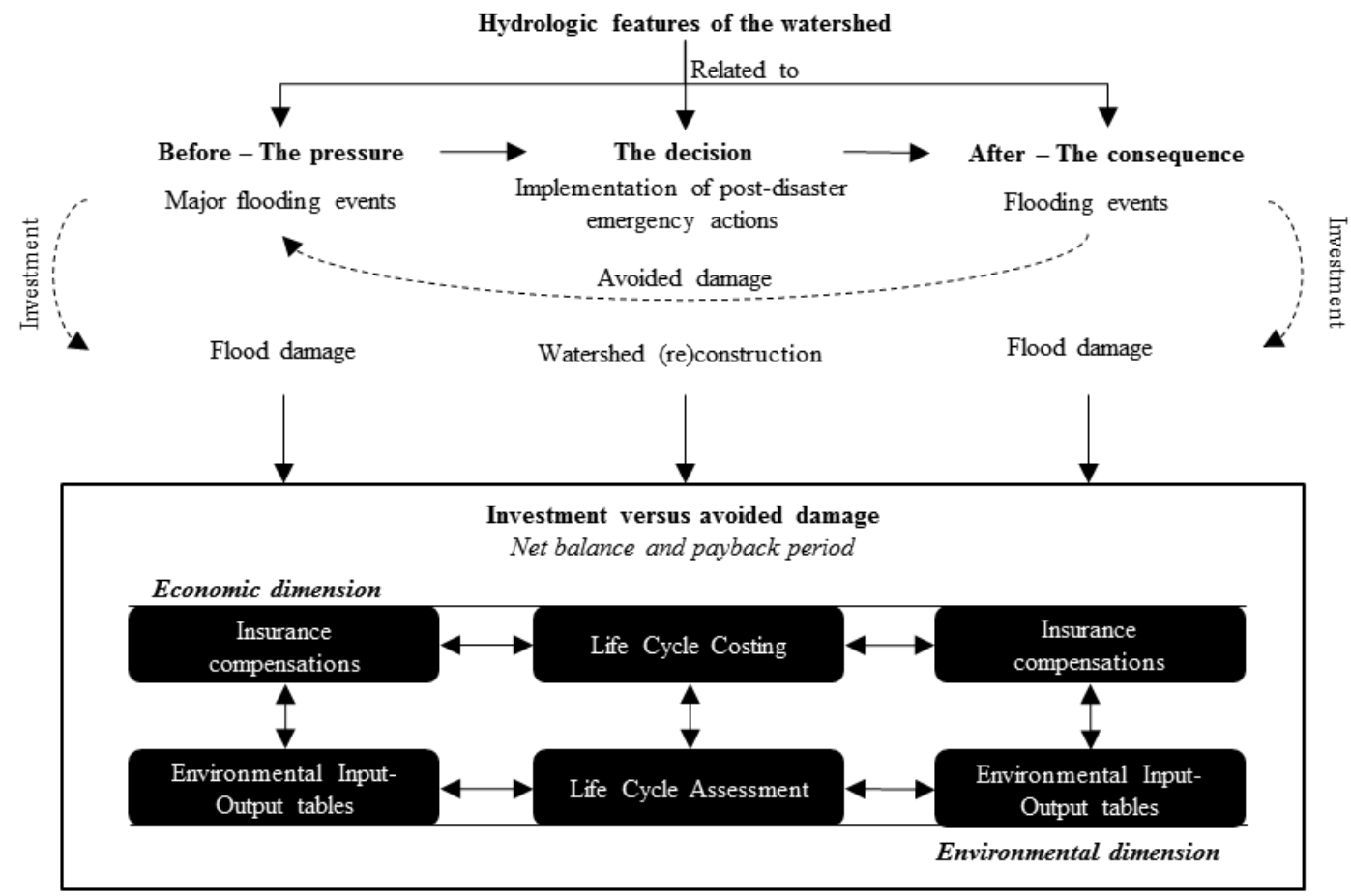

Figure 1 Integrated method for estimating the net impacts and payback period of flood post-disaster emergency actions 


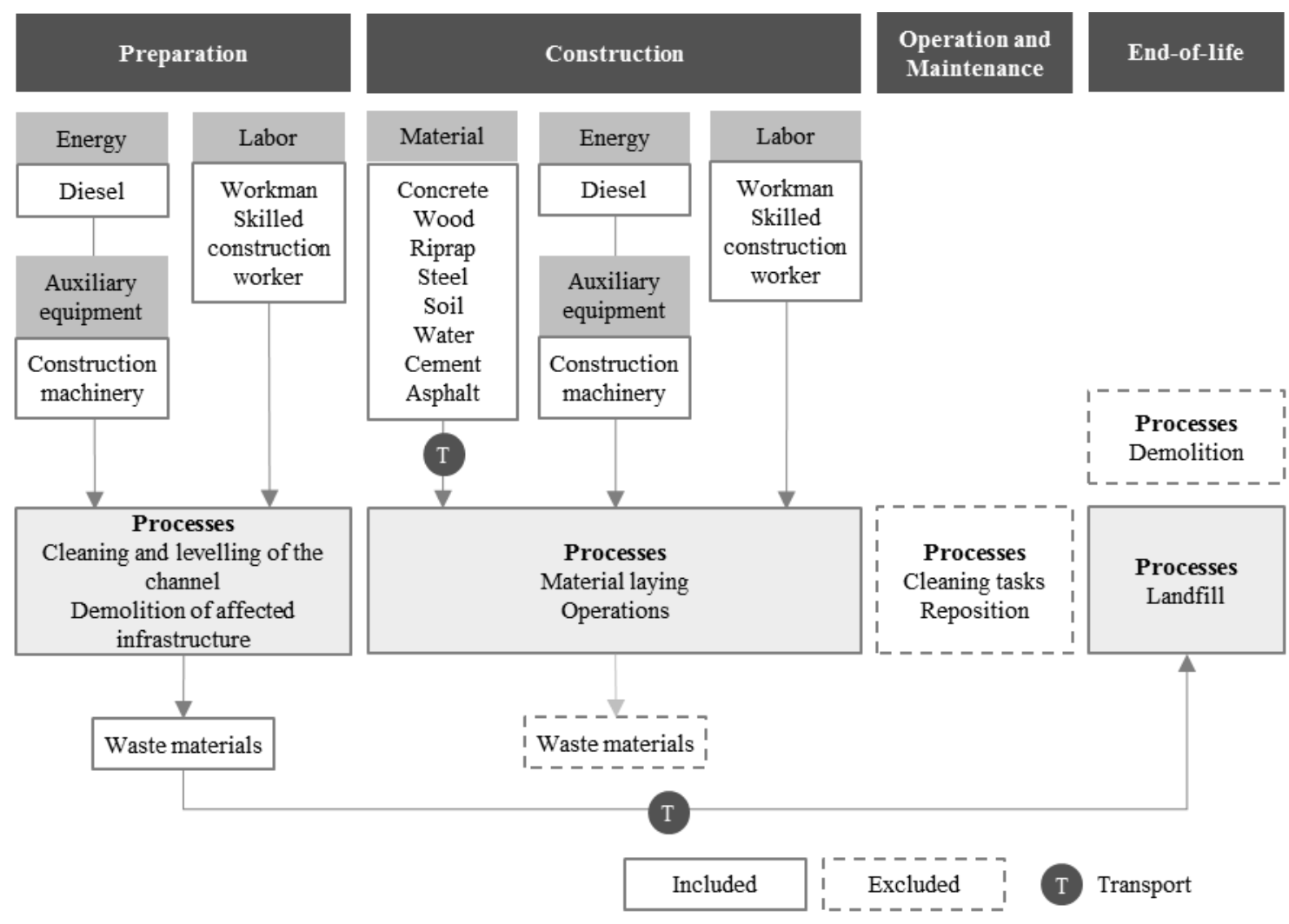

Figure 2 System boundaries of the life cycle of the emergency actions analyzed 


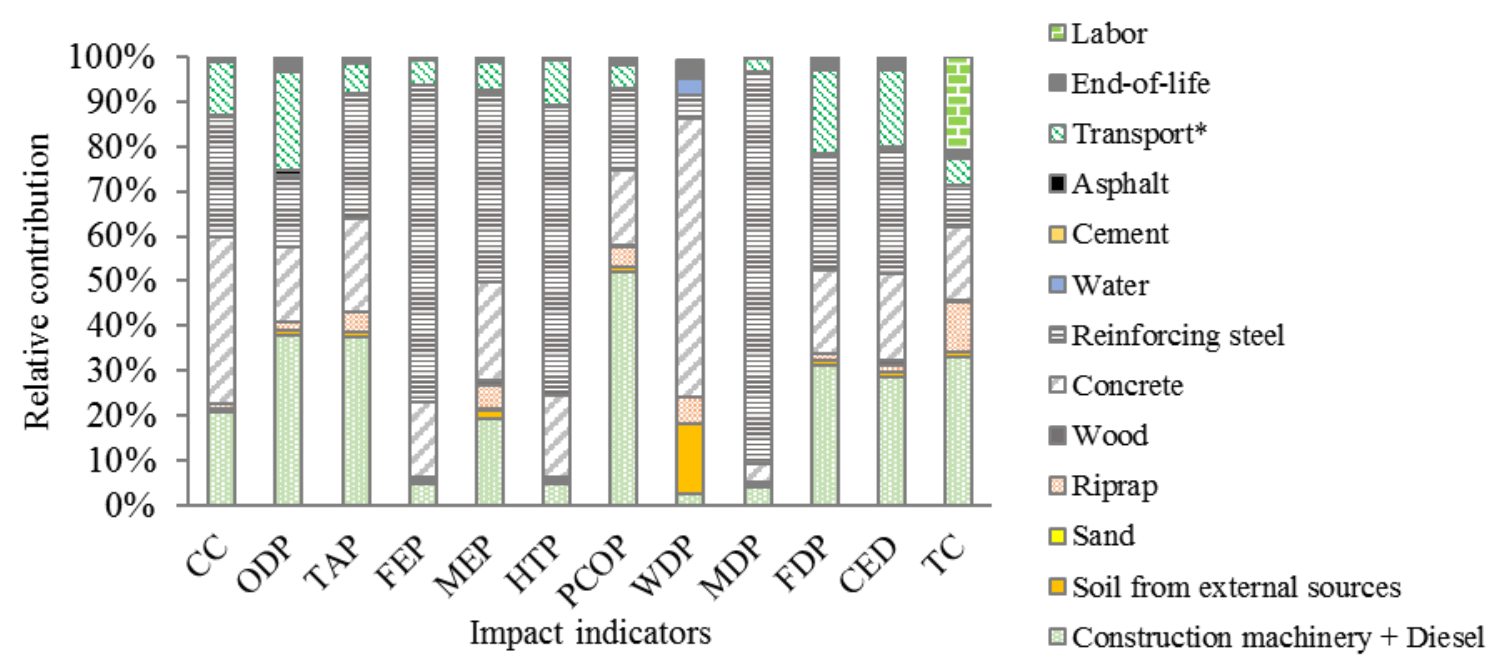

Figure 3 Breakdown of the relative contribution of the processes involved in the emergency actions to the impact indicators. * In TC, the transport cost is related to material transfers within the construction site; material transport costs are embedded in the cost of each material 

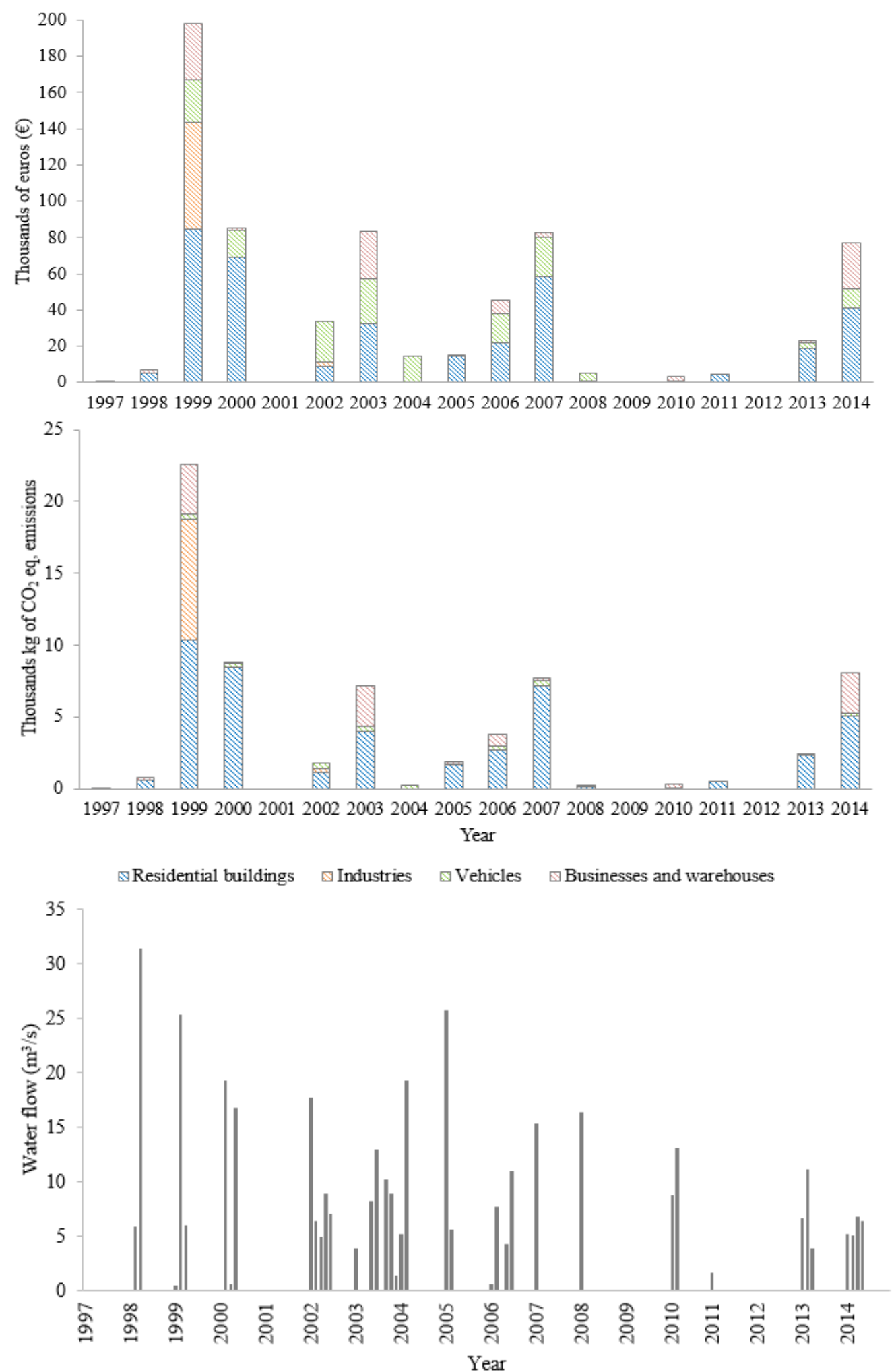

Figure 4 Environmental and economic impacts related to different types of flood damage recorded in the study area, and evolution of the water flow for each event with recorded damage 
Table 1 Features and location of the post-disaster emergency actions implemented after the 1996 flooding. Data from the archive of the Catalan Water Agency (2015). Basemap from ICGC (2016). Vilassar: Stream A; Cabrils: Stream B; and Cintet: Stream C

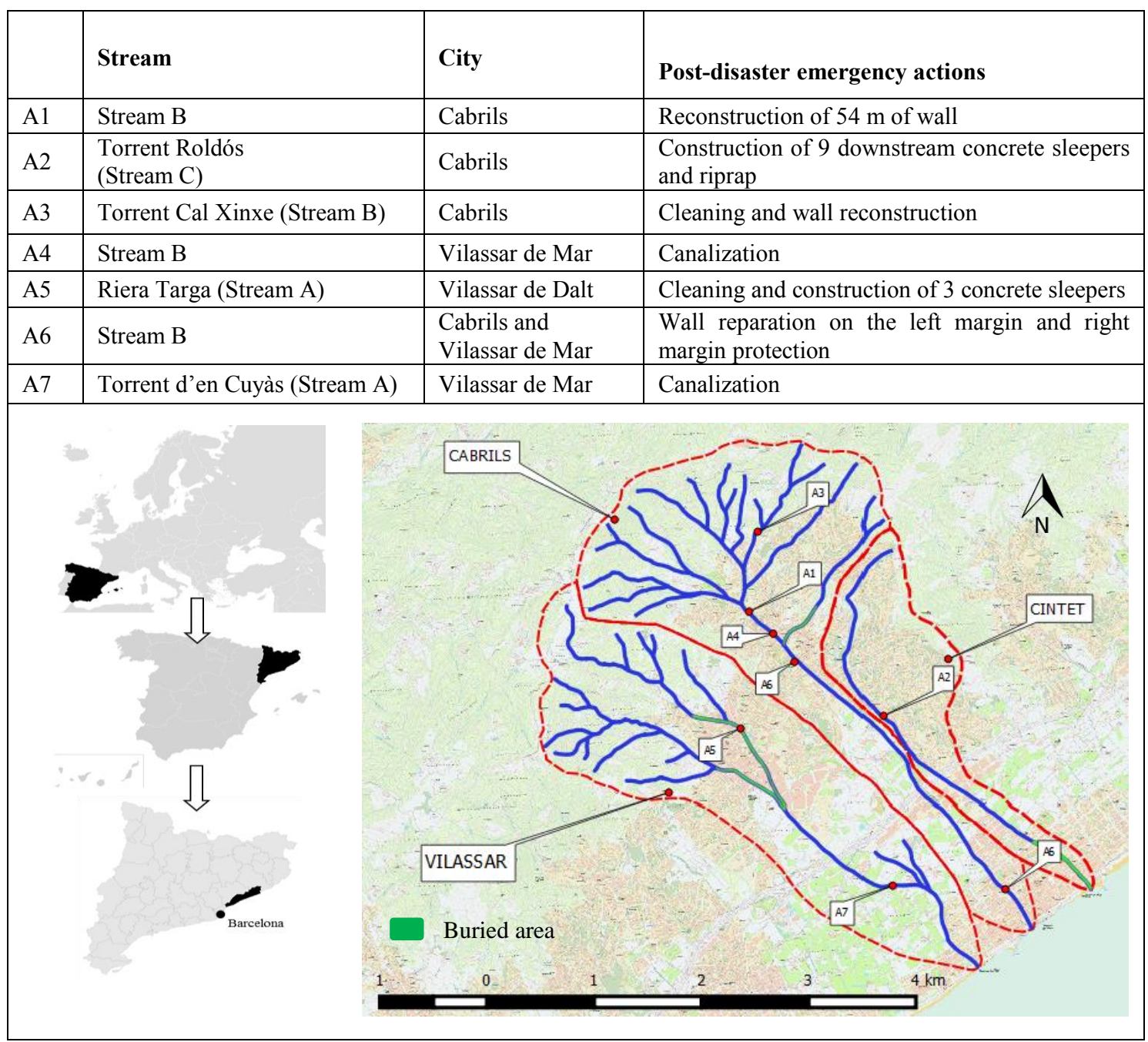


Table 2 Estimation of the $\mathrm{CO}_{2}$ eq. emissions of the damage categories through input-output tables. Based on data from the Spanish Statistical Office (INE, 2015, 2014)

\begin{tabular}{|c|c|c|c|c|c|c|c|}
\hline \multirow[b]{2}{*}{ Selected economic sectors } & \multicolumn{4}{|c|}{ Damage categories } & \multicolumn{3}{|c|}{ Input-output values } \\
\hline & 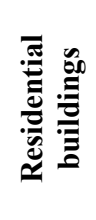 & 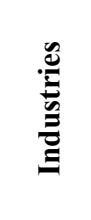 & $\frac{\mathscr{e}}{\stackrel{0}{e}}$ & 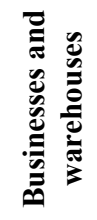 & $\begin{array}{l}\text { Total output } \\
\quad\left(\times 10^{6} €\right)\end{array}$ & $\begin{array}{c}\text { Total } \\
\text { greenhouse gas } \\
\text { emissions }\left(x 1^{3}\right. \\
\left.\text { tons of } \mathrm{CO}_{2} \text { eq. }\right)\end{array}$ & $\begin{array}{c}\text { Sectorial impact } \\
\text { factor }\left(\mathrm{kg} \mathrm{CO}_{2}\right. \\
\text { eq. } / €)\end{array}$ \\
\hline Food products and beverages & $\times$ & & & $x$ & $1.8 \mathrm{E}+05$ & $5.9 \mathrm{E}+03$ & 0.032 \\
\hline Textile products & $\times$ & & & $x$ & $6.0 \mathrm{E}+04$ & $6.8 \mathrm{E}+02$ & 0.011 \\
\hline Paper and related products & $x$ & $x$ & & $x$ & $1.8 \mathrm{E}+04$ & $2.8 \mathrm{E}+03$ & 0.153 \\
\hline Electronics & $x$ & $x$ & & $x$ & $3.9 \mathrm{E}+04$ & $1.4 \mathrm{E}+02$ & 0.004 \\
\hline Electric equipment & $\times$ & $x$ & $x$ & $x$ & $3.4 \mathrm{E}+04$ & $6.6 \mathrm{E}+02$ & 0.019 \\
\hline Furniture & $x$ & & & & $3.6 \mathrm{E}+04$ & $4.7 \mathrm{E}+02$ & 0.013 \\
\hline $\begin{array}{l}\text { Repair services and installation of } \\
\text { machinery and equipment }\end{array}$ & $x$ & $x$ & $x$ & $x$ & $2.0 \mathrm{E}+04$ & $9.4 \mathrm{E}+01$ & 0.005 \\
\hline $\begin{array}{l}\text { Electricity, gas, vapor and air } \\
\text { conditioning }\end{array}$ & $\times$ & $\times$ & & $x$ & $8.5 \mathrm{E}+04$ & $7.3 \mathrm{E}+04$ & 0.863 \\
\hline Construction activities & $x$ & $x$ & & $\times$ & $2.3 \mathrm{E}+05$ & $1.1 \mathrm{E}+03$ & 0.005 \\
\hline $\begin{array}{l}\text { Wood and cork and related } \\
\text { products }\end{array}$ & & $x$ & & & $1.1 \mathrm{E}+04$ & $7.6 \mathrm{E}+02$ & 0.067 \\
\hline Machinery & & $\times$ & $\times$ & & $4.1 \mathrm{E}+04$ & $6.6 \mathrm{E}+02$ & 0.016 \\
\hline Motorized vehicles & & & $x$ & & $8.1 \mathrm{E}+04$ & $1.5 \mathrm{E}+03$ & 0.018 \\
\hline Lodging services & & & & $\times$ & $1.1 \mathrm{E}+05$ & $1.9 \mathrm{E}+03$ & 0.017 \\
\hline Sports and leisure centers & & & & $x$ & $1.7 \mathrm{E}+04$ & $4.5 \mathrm{E}+01$ & 0.003 \\
\hline $\begin{array}{c}\text { Average impact factor }(\mathrm{kg} \mathrm{CO} 2 \\
\text { eq./€) }\end{array}$ & 0.123 & 0.142 & 0.015 & 0.111 & & & \\
\hline
\end{tabular}


Table 3 Events with relevant water flows and associated damage. T: return period; RC: Threshold runoff coefficient at intervals

\begin{tabular}{|c|c|c|c|c|c|c|}
\hline Date & $\begin{array}{c}\text { Expected } \\
\text { water } \\
\text { flow in } \\
\text { the } \\
\text { watershed } \\
\left(Q_{p}\right) \\
(T=50 \\
\text { years) }\end{array}$ & $\begin{array}{c}\text { Water } \\
\text { flow } \\
(\mathbf{Q}) \\
(\mathbf{R C}=\mathbf{0 . 4}) \\
\left(\mathbf{m}^{3} / \mathbf{s}\right)\end{array}$ & $\begin{array}{c}\text { Water } \\
\text { flow }(\mathbf{Q}) \\
(\mathbf{R C}=\mathbf{0 . 6}) \\
\left(\mathbf{m}^{3} / \mathbf{s}\right)\end{array}$ & $\begin{array}{c}\text { Accumulated } \\
\text { rainfall } \\
(\mathbf{m m} / \text { day })\end{array}$ & $\begin{array}{c}\text { Maximum } \\
\text { rainfall } \\
\text { intensity (I) } \\
(\mathbf{m m} / \mathbf{h})\end{array}$ & $\begin{array}{c}\text { Economic } \\
\text { compensation } \\
(€)\end{array}$ \\
\hline 2-Sep-1996 & \multirow{4}{*}{78.2} & 42 & 64 & 158 & 176 & $2,533,267$ \\
\hline 3-Dec-1998 & & 31 & 47 & 116 & 55 & 4,372 \\
\hline 14-Sep-1999 & & 25 & 38 & 93 & 132 & 116,892 \\
\hline 19-Sep-2000 & & 16 & 25 & 62 & 175 & 54,162 \\
\hline
\end{tabular}

Table 4 Total environmental and economic impacts of the emergency actions given a lifespan of 50 years

\begin{tabular}{|l|l|c|c|c|}
\hline \multicolumn{1}{|c|}{ Impact category } & \multicolumn{1}{c|}{ Unit } & Acronym & Result & Eco-efficiency ratio \\
\hline Climate Change Potential & $\mathrm{kg} \mathrm{CO}_{2}$ eq. & $\mathrm{CC}$ & $3.9 \mathrm{E}+06$ & $1.2 \mathrm{E}+00$ \\
\hline Ozone Depletion Potential & $\mathrm{kg} \mathrm{CFC}-11$ eq. & ODP & $3.8 \mathrm{E}-01$ & $1.2 \mathrm{E}-07$ \\
\hline Terrestrial Acidification Potential & $\mathrm{kg} \mathrm{SO}_{2}$ eq. & TAP & $1.7 \mathrm{E}+04$ & $5.3 \mathrm{E}-03$ \\
\hline Freshwater Eutrophication Potential & $\mathrm{kg} \mathrm{P} \mathrm{eq.}$ & FEP & $6.6 \mathrm{E}+02$ & $2.1 \mathrm{E}-04$ \\
\hline Marine Eutrophication Potential & $\mathrm{kg} \mathrm{N}$ eq. & $\mathrm{MEP}$ & $2.3 \mathrm{E}+03$ & $7.2 \mathrm{E}-04$ \\
\hline Human Toxicity Potential & $\mathrm{kg} 1,4-\mathrm{DB}$ eq. & $\mathrm{HTP}$ & $9.1 \mathrm{E}+05$ & $2.8 \mathrm{E}-01$ \\
\hline $\begin{array}{l}\text { Photochemical Oxidant Formation } \\
\text { Potential }\end{array}$ & $\mathrm{kg} \mathrm{NMVOC}$ & $\mathrm{PCOP}$ & $2.1 \mathrm{E}+04$ & $6.6 \mathrm{E}-03$ \\
\hline Water Depletion Potential & $\mathrm{m}^{3}$ & $\mathrm{WDP}$ & $2.4 \mathrm{E}+04$ & $7.5 \mathrm{E}-03$ \\
\hline Metal Depletion Potential & $\mathrm{kg} \mathrm{Fe}$ eq. & $\mathrm{MDP}$ & $7.1 \mathrm{E}+05$ & $2.2 \mathrm{E}-01$ \\
\hline Fossil Depletion Potential & $\mathrm{kg}$ oil eq. & FDP & $8.9 \mathrm{E}+05$ & $2.8 \mathrm{E}-01$ \\
\hline Cumulative Energy Demand & $\mathrm{MJ}$ & $\mathrm{CED}$ & $4.4 \mathrm{E}+07$ & $1.4 \mathrm{E}+01$ \\
\hline Total Cost & $€$ & $\mathrm{TC}$ & $3.2 \mathrm{E}+06$ & - \\
\hline
\end{tabular}


Table 5 Environmental and economic balance of the emergency actions based on the avoided flood events

\begin{tabular}{|l|r|l|r|l|}
\cline { 2 - 6 } \multicolumn{1}{c|}{} & \multicolumn{2}{c|}{ Economic balance } & \multicolumn{2}{c|}{$\begin{array}{c}\text { Environmental } \\
\text { balance }\end{array}$} \\
\hline Parameters & Value & \multicolumn{1}{c|}{ Units } & \multicolumn{1}{c|}{ Value } & \multicolumn{1}{c|}{ Units } \\
\hline Average \# events per year & 2.7 & $\mathrm{u}$ & 2.7 & $\mathrm{u}$ \\
\hline Lifespan of the actions & 50 & years & 50 & years \\
\hline Initial investment & $3.2 \mathrm{E}+06$ & $€$ & $3.9 \mathrm{E}+06$ & $\mathrm{~kg} \mathrm{CO}_{2}$ eq. \\
\hline Average recorded damage per event & $1.4 \mathrm{E}+04$ & $€$ & $1.4 \mathrm{E}+03$ & $\mathrm{~kg} \mathrm{CO}_{2}$ eq. \\
\hline Estimated average do-nothing damage per event & $5.6 \mathrm{E}+05$ & $€$ & $5.9 \mathrm{E}+04$ & $\mathrm{~kg} \mathrm{CO}_{2}$ eq. \\
\hline Estimated avoided damage per event & $5.4 \mathrm{E}+05$ & $€$ & $5.8 \mathrm{E}+04$ & $\mathrm{~kg} \mathrm{CO}_{2}$ eq. \\
\hline Net impact per event & $-5.2 \mathrm{E}+05$ & $€$ & $-2.9 \mathrm{E}+04$ & $\mathrm{~kg} \mathrm{CO}_{2}$ eq. \\
\hline Payback period & 5 & events & 67 & events \\
& 2 & years & 25 & years \\
\hline
\end{tabular}

